$0.4974 \mathrm{I}, \eta_{50} / \eta_{0 \circ}=0.30640$ and $\eta_{50} / \eta_{25} \circ=0.6 \mathrm{I} 599$. They are probably accurate to $0.03 \%$.

3. The relative viscosity of a normal solution of potassium chloride at $1.8^{\circ}$ is $0.98 \mathrm{I} 3^{\circ}$.

URBANA, ILL.

[Contribution from the Laboratory of Physical Chemistry of the Untversity of Ilimois. Publication No. 15.]

\title{
THE VISCOSITIES AND CONDUCTIVITIES OF AQUEOUS SOLUTIONS OF RAFFINOSE.
}

\author{
By EDWARD W. Washburn and GUY Y. WiLliams.
}

Received April 26, 1913

Introduction.

In the second paper ${ }^{1}$ in the series on "Concentrated Solutions" a method formaking the viscosity correction in computing degrees of ionization was proposed, based upon the relation, $\Lambda=k f^{m}$, where $\Lambda$ is the equivalent conductance of an ion in a medium of fluidity, $f, k$ is a constant and $m$ is also a constant, not far from unity, which depends upon the nature of the ion. The evidence supporting this relation was largely confined to solutions in which the fluidity was varied by varying the temperature and in those cases the above relation is known to hold very exactly for all ions except hydrogen and hydroxyl. As pointed out in the paper referred to, it is very desirable to obtain further evidence regarding the applicability of this relation and especially to discover to what extent the value of the fluidity exponent $m$, is influenced by the nature of the molecules which determin the fluidity of the medium through which the ion moves. Some experiments by Green, in which the conductivity of lithium chloride was studied in aqueous solutions of cane sugar, were also discussed and, as far as could be determined, his data seemed to confirm the relation, $\Lambda=k f^{m}$, in the case of this salt.

In continuing the investigation of the relation between ion conductances and the viscosity of the medium, we have chosen raffinose as the first noneleetrolyte to be employed for changing the viscosity. Owing to the high molecular weight of raffinose comparatively large changes in the viscosity can be produced without changing the activity of the water very much. This is important becauss it is essential in the first experiments that the degrees of hydration of the ions remain constant. Another advantage of raffinose over cane sugar is its stability in solution. Cane sugar slowly decomposes, especially in the conductivity eell under the catalytic influence of the platinum electrodes, and this decomposition results in an increased and uncertain conductivity and constitutes a considerable source of error. Raffinose, as shown below, is quite free from this objection. A further

I Washburn, THIS JourNal, 33, I46I (IgII). 
advantage in using raffinose lies in the fact that the results of the investigation can be easily correlated with the data concerning true transference numbers in solutions in which raffinose serves as the reference substance. The present paper is a preliminary one dealing with the preparation of pure raffinose and the conductivity and viscosity of its solutions.

\section{Purification of the Raffinose.}

The data required in the proposed investigation are the $\Lambda_{\circ}$ values for a number of strong electrolytes in aqueous solutions of raffinose. In order to obtain the $\Lambda_{0}$ value with a reasonable degree of accuracy it is necessary that the solvent, itself, in this case the raffinose solution, have a very low specific conductance so that the conductance measurements of the salt solutions may be carried to high dilutions. A very high degree of purity, especially with regard to freedom from electrolytes, is therefore necessary on the part of the raffinose. This was secured by the following process of purification.

Kahlbaum's raffinose was employed as the "raw material." Its specific conductance in 0.1 molal solution at room temperature was $17.10^{-6}$ reciprocal ohms. An excess of the crystals was treated with hot, dry, methyl alcohol (Kahlbaum's best grade, distilled from metallic calcium) and the clear solution decanted off from the residue. This solution was then cooled in a freezing mixture. The raffinose which precipitated out as a viscous mass was dissolved in conductivity water and the solution concentrated by evaporation in a platinum or quartz vessel. The syrup thus obtained was then poured into a wide-mouthed quartz flask and while still hot was treated with pure ethyl alcohol in small portions until the precipitate which was formed just failed to dissolve on shaking. The flask was then set aside and the raffinose allowed to crystallize. The crystals were centrifuged in platinum and then recrystallized until the product had a specific conductance in 0.1 molal solution at $25^{2}$ of less than $2.10^{-6}$ reciprocal ohms. The final product was dried at $50^{\circ}-60^{\circ}$ in an electric oven.

\section{The Conductivity Water.}

The water was distilled from an alkaline permanganate solution. The distillate was collected hot, in 3 -liter quartz flasks, and had an average specific conductance at $25^{\circ}$ of $0.6 \cdot 10^{-6}$ reciprocal ohms. The best water obtained in this way during the course of the work had a specific conductance at $25^{\circ}$ of only $0.19 \cdot 10^{-6}$ reciprocal ohms. This water after standing over night in the quartz flask covered with tin foil had a specific conductance of $0.36 .10^{-8}$. At the end of 48 hours it had increased to $0.61 .10^{-8}$ and at the end of two weeks it was only 0.68.10-8.

\section{The Conductance Cell.}

This was of the pipet type and is shown in Fig. I. It was constructed of Jena Geräteglas and provided with two circular electrodes $2 \mathrm{~cm}$. in 
diameter and $3 \mathrm{~mm}$. apart. The inner face of each electrode had been roughened by means of a sand blast. Two ground glass caps closed the

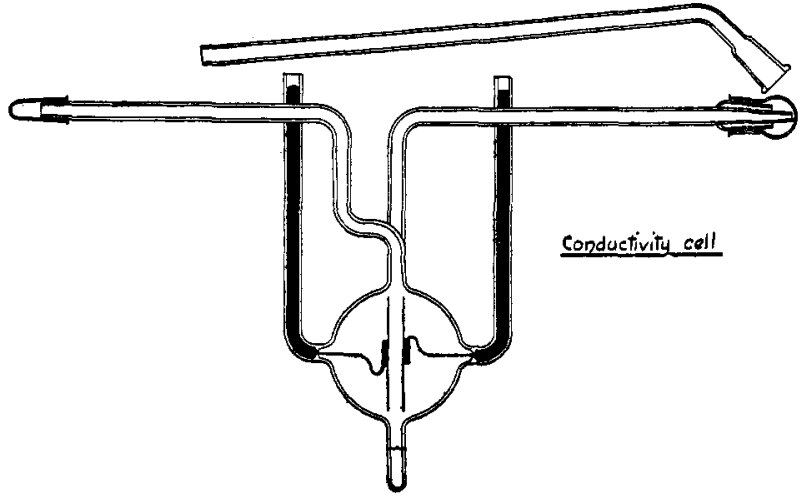

Fig. I.

cell after filling. The conductance measurements were made with the improved conductivity apparatus of Washburn and Bell. ${ }^{1}$

\section{The Conductance Measurements.}

The raffinose crystals after drying for 2 hours at $50^{\circ}-60^{\circ}$ in a platinum dish, were transferred hot to a weighed quartz flask and allowed to cool in a desiccator. After weighing, the proper amount of conductivity water was weighed in by means of a quartz pipet. When solution was complete the conductance cell was filled through the detachable tube $T$, shown in the figure, and after closing by means of the glass caps was placed in the constant temperature bath described in the preceding paper. The conductances were perfectly constant over a long period of time.

The conductance data are shown in Table $I$. The values given in column VI were obtained by subtracting, from the corresponding values in column $\mathrm{V}$, the specific conductance of the water divided by the viscosity of the solution. The very low values of the specific conductances of the raffinose indicate a high degree of purity. The sucrose employed by Green in the investigation referred to, had a specific conductance in $0.2 \mathrm{molal}$ normal solution of $13.8 .10^{-6}$ reciprocal ohms at $25^{\circ} .^{2}$

\section{The Ionization Constant of Raffinose as an Acid.}

The values of the equivalent conductance given in column VI of Table I may be employed to calculate the order of magnitude of the ionization constant of raffinose as an acid. For this purpose they were first multiplied by the viscosity of the solution and then substituted in the equation $\Lambda^{2} \mathrm{C} / \Lambda^{2}{ }_{\circ}=\mathrm{K}$, and the values of $\mathrm{K}$ given in column VII obtained. For $\Lambda_{\circ}$

${ }^{2}$ Washburn and Bell, This Journal, 35, 177 (I9I3).

${ }^{2}$ Green, J. Chem. Soc., 94, 2056 (1908); cf. Washburn, Z. Ver. Deut. Zuckerind., 60, 38I (IgIo). 
the values, 250 at $0^{\circ}$ and 370 at $25^{\circ}$ were employed. The values of $\mathrm{K}$ thus obtained, $0.5 \cdot 10^{-10}$ at $0^{\circ}$ and $0.9 \cdot 10^{-10}$ at $25^{\circ}$, can, of course, be regarded as maximum values only.

Table I.-Conductances of Aqueous Solutions of Raffinose.

\begin{tabular}{|c|c|c|c|c|c|c|}
\hline $\begin{array}{c}\text { I. } \\
\text { Formula } \\
\text { weights of } \\
\mathrm{C}_{18} \mathrm{H}_{32} \mathrm{O}_{16}, 5 \mathrm{H}_{2} \mathrm{O} \\
\text { per liter, } \\
\text { at } t^{\circ} .\end{array}$ & Temperature. & $\begin{array}{c}\text { III. } \\
\text { Specific } \\
\text { conductance } \\
\text { of the water } \\
\times 10^{6} .\end{array}$ & $\begin{array}{l}\text { IV. } \\
\text { Specific con- } \\
\text { ductance of } \\
\text { the solution } \\
\times 10^{6} .\end{array}$ & $\begin{array}{l}\text { V. } \\
\text { Corrected } \\
\text { specific con- } \\
\text { ductance of } \\
\text { the solution } \\
\times 10^{6} .\end{array}$ & $\begin{array}{l}\text { VI. } \\
\text { Equiva- } \\
\text { lent con- } \\
\text { ductance of } \\
\text { the raffinose } \\
\Delta \times 10^{3}\end{array}$ & $\begin{array}{c}\text { ViI. } \\
\text { Ionization } \\
\text { constant } \\
\text { of raffinose } \\
\text { as an acid } \\
\mathrm{K} \times 10^{10} \text {. }\end{array}$ \\
\hline 0.200 & $0.00^{\circ}$ & 0.15 & 0.600 & 0.49 & 2.5 & 0.4 \\
\hline o. 197 & $25.00^{\circ}$ & 0.35 & I. 24 & 1.00 & 5.0 & 0.8 \\
\hline 0.0349 & $0.00^{\circ}$ & 0.15 & 0.42 & $0.3 \mathrm{I}$ & 8.9 & 0.5 \\
\hline 0.0346 & $25.0^{\circ}$ & 0.35 & 0.89 & 0.64 & 18.0 & 0.9 \\
\hline
\end{tabular}

7. The Viscosity Measurements.

The solutions prepared as described in the preceding section were filtered through hardened filters which had been previously washed and dried. The set of weights used in preparing the solutions and in the density measurements had been carefully standardized against a set certified to by the Bureau of Standards. All weights were reduced to vacuo. The viscosities were measured as described in the preceding paper. The results are tabulated below:

Table II.-Densities and Relative Viscosities of Aqueous Solutions of RaFFINOSE.

\begin{tabular}{|c|c|c|c|c|c|c|}
\hline \multirow[t]{2}{*}{$\begin{array}{l}\text { Formula weights } \\
\text { per liter at } t^{\circ} \text {. }\end{array}$} & $\begin{array}{l}\text { Temper- } \\
\text { ature. }\end{array}$ & $\begin{array}{l}\text { Times } \\
\text { of flow. }\end{array}$ & $\begin{array}{l}\text { Mean time } \\
\text { of flow. }\end{array}$ & $\begin{array}{l}\text { Density } \\
\text { at } t^{\circ} / t^{\circ} \text {. }\end{array}$ & $\begin{array}{l}\text { Relative } \\
\text { viscosity. }\end{array}$ & $\begin{array}{l}\text { Relative viscos- } \\
\text { ity at round } \\
\text { temperatures. }\end{array}$ \\
\hline & & $1224 \cdot 44$ & & & & \\
\hline \multirow[t]{3}{*}{0.038083} & $0.00^{\circ}$ & .53 & $1224 \cdot 46$ & I.00796 & I. .06284 & 1. 06284 \\
\hline & & .42 & & & & \\
\hline & & $607 \cdot 76$ & & & & \\
\hline \multirow[t]{2}{*}{0.037973} & $24.94^{\circ}$ & $\begin{array}{l}.77 \\
.58 ?\end{array}$ & $607 \cdot 76$ & 1.00483 & 1.05604 & 1.05602 \\
\hline & & 375.01 & & & & \\
\hline \multirow[t]{2}{*}{0.037615} & $49.87^{\circ}$ & .04 & 375.03 & 0.99556 & I. 04728 & 1.04723 \\
\hline & & $\mathrm{I} 263 \cdot 30$ & & & & \\
\hline \multirow[t]{3}{*}{0.058632} & $0.00^{\circ}$ & .39 & $1263 \cdot 42$ & I. 01218 & I. 10129 & I. IOI 29 \\
\hline & & .57 & & & & \\
\hline & & 623.69 & & & & \\
\hline \multirow[t]{2}{*}{0.058466} & $24.94^{\circ}$ & $\begin{array}{l}.66 \\
.63\end{array}$ & 623.66 & I. 00897 & 1.08812 & I.08809 \\
\hline & & $384 \cdot 38$ & & & & \\
\hline \multirow[t]{4}{*}{0.057925} & $49.87^{\circ}$ & .44 & $384 \cdot 4 I$ & 0.99964 & I. 07787 & I. 07780 \\
\hline & & .42 & & & & \\
\hline & & $.4 I$ & & & & \\
\hline & & $I 35 I .43$ & & & & \\
\hline o. 102676 & $0.00^{\circ}$ & .76 & I 35 I. 43 & 1.02147 & I. I $888 \mathrm{I}$ & I. I 888 I \\
\hline
\end{tabular}




\begin{tabular}{|c|c|c|c|c|c|c|}
\hline $\begin{array}{l}\text { Formula weights } \\
\text { per liter at } t^{\circ} \text {. }\end{array}$ & $\begin{array}{l}\text { Temper- } \\
\text { ature. }\end{array}$ & $\begin{array}{l}\text { Times } \\
\text { of flow. }\end{array}$ & $\begin{array}{l}\text { Mean time } \\
\text { of flow. }\end{array}$ & $\begin{array}{l}\text { Density } \\
\text { at } t^{\circ} / t^{\circ} \text {. }\end{array}$ & $\begin{array}{l}\text { Relative } \\
\text { viscosity. }\end{array}$ & $\begin{array}{l}\text { Relative viscos- } \\
\text { ity at round } \\
\text { temperatures. }\end{array}$ \\
\hline 0.102297 & $24.94^{\circ}$ & $\begin{array}{r}659.87 \\
.80 \\
.83 \\
.84\end{array}$ & 659.84 & 1.01179 & I. I6268 & I. 16262 \\
\hline 0.13 I 202 & $0.00^{\circ}$ & $\begin{array}{r}1415.08 \\
.00 \\
.55 \\
.36\end{array}$ & 1415.25 & I. $.0275^{2}$ & I.25233 & I. 25233 \\
\hline 0.130727 & $\cdot 24.96^{\circ}$ & $\begin{array}{r}687.39 \\
.25 \\
.10\end{array}$ & 687.25 & I. 02378 & 1.21719 & 1.21713 \\
\hline 0.129787 & $50.12^{\circ}$ & $\begin{array}{r}417.59 \\
.34 \\
.56 \\
.45\end{array}$ & 417.49 & I.OI 407 & I. I926I & I. 19272 \\
\hline 0.176625 & $0.00^{\circ}$ & $\begin{array}{r}1524 \cdot 40 \\
.00 \\
.25\end{array}$ & 1524.22 & 1.03645 & I. 36048 & I. 36048 \\
\hline 0.175818 & $25.00^{\circ}$ & $\begin{array}{r}734 \cdot 50 \\
.75 \\
.74\end{array}$ & 734.66 & 1.03192 & 1.31230 & 1.31230 \\
\hline 0.174336 & $49.84^{\circ}$ & $\begin{array}{r}443.06 \\
.00 \\
.13\end{array}$ & 443.06 & 1.02302 & I. 27083 & 1.27057 \\
\hline
\end{tabular}

[Contribution from the Chemical Laboratories of New Hampshire College.]

\section{NEODYMIUM OXALATE AND SOME NEW COMPOUNDS OF EUROPIUM.}

BY C. JAMES AND J. E. ROBINSON.

Received April 21, 1913.

The first part of this research was to determin the solubility of neodymium oxalate in solutions of neodymium nitrate of various concentrations; for the curve obtained would then show whether hydrates of neodymium oxalate other than $\mathrm{Nd}_{2}\left(\mathrm{C}_{2} \mathrm{O}_{4}\right)_{3}$. $\mathrm{IH}_{2} \mathrm{O}$ existed in contact with neodymium nitrate at $25^{\circ}$, and whether it was possible for an oxalonitrate to be formed under similar conditions.

In the second portion of the work, some new compounds of europium were prepared in the endeavor to find some salt or salts suitable for an equivalent determination or else useful for the purification of this element.

Neodymium Oxalate.-Pure neodymium magnesium nitrate was dissolved in water, making a fairly dilute solution, and precipitated while boiling, by the addition of hot oxalic acid solution. The oxalate was filtered off 